\title{
APRENDER A APRENDER SOBRE ALIANÇA: COMUNICAÇÃO INTERMUNDOS A PARTIR DO ENCONTRO COM UM CASAL DE XAMÃs KAIOWÁ
}

\author{
LUCIANA DE OLIVEIRA ${ }^{1}$
}

\begin{abstract}
RESUMO
0 artigo é uma reflexão em torno de experiências de ensino-aprendizagem calcadas em prática etnográfica multissituada (2012-ATUAL) que incluem os processos formativos de um projeto de ensino de graduação e se desdobra em dois níveis: 1) um de caráter descritivo de algumas das práticas pedagógicas de um casal de xamãs Kaiowá em três cursos ditados por eles - dois por Valdomiro Flores em 2014 e 2016 e um por Tereza Amarília Flores em 2018 bem como em seu território originário, a retomada de Guaiviry Yvy Pyte Y Jere (município de Aral Moreira, Mato Grosso do Sul); 2) outro de caráter proposicional, sugere pensar 0 encontro de saberes como conduta nas práticas de comunicação intermundos para aprender a aprender sobre aliança.
\end{abstract}

\section{PaLAVRAS-ChAVE}

Xamanismo Kaiowá; Encontro de Saberes; Comunicação Intermundos; Aliança.

\section{LEARNING TO LEARN ABOUT ALLIANCE: INTERWORLD COMMUNICATION FROM THE MEETING WITH A COUPLE OF KAIOWA SHAMANS}

\begin{abstract}
This is a reflection paper on teaching-learning experiences based on multi-sited ethnographic practice (2012CURRENT) that include the formative processes of an undergraduate training project and it unfolds at two levels: 1) a descriptive one is about some of the pedagogical practices of a couple of Kaiowa shamans in three courses taught by them - two by Valdomiro Flores in 2014 and 2016 and one by Tereza Amarília Flores in 2018 as well as in their original territory, the resumption of Guaiviry Yvy Pyte Y Jere (Aral Moreira, Mato Grosso do Sul, Brazil); 2) another one, with a propositional character, suggests thinking about the meeting of knowledge as a conduct in interworld communication practices to learn how to learn about alliance.
\end{abstract}

\section{KEYWORDS}

Kaiowa Shamanism; Meeting of Knowledge; Between-Worlds Communication; Alliance.

\section{APPRENDRE À APPRENDRE SUR L'ALLIANCE: COMMUNICATION ENTRE LES MONDESÀ PARTIR DE LA RENCONTRE AVEC UN COUPLE DE CHAMANS KAIOWA}

\footnotetext{
1 Professora associada e pesquisadora-extensionista no Programa de Pós-Graduação e no Departamento de Comunicação Social da UFMG, onde atua também no grupo gestor da Formação Transversal em Saberes Tradicionais (2014- Atual). É líder do Grupo de Pesquisa Corisco (Coletivo de Estudos, Pesquisas Etnográficas e Ação Comunicacional em Contextos de Risco). Desde 2012, desenvolve trabalhos e pesquisas em colaboração com a comunidade do povo Kaiowá de Guaiviry Yvy Pyte Y Jere em Mato Grosso do Sul, com produções em cinema, artes visuais, redes digitais e editoriais. É co-organizadora, junto com o casal de rezadores Kaiowá Valdomiro Flores e Tereza Amarília Flores, do livro Ñe'e Tee Rekove/Palavra Verdadeira Viva (2020) e co-autora do livro-objeto Tee: amboe oguahema omburahei ha oñembosarai haguã/Desc endentes: Outros que chegam para rezar e brincar com Paulo Nazareth. Email: luciana.lucyoli@gmail.com
} 


\section{RESUMÉ}

L'article est une réflexion sur les expériences d'enseignement-apprentissage basées sur une pratique ethnographique multisituée (2012-ACTUEL) qui comprend les processus de formation d'un projet d'enseignement de premier cycle et se déroule à deux niveaux: 1) un à caractère descriptif de certaines des pratiques pédagogiques d'un couple de chamans Kaiowá dans trois cours dispensés par eux - deux par Valdomiro Flores en 2014 et 2016 et un par Tereza Amarília Flores en 2018 ainsi que dans leur territoire d'origine, la reprise de Guaiviry Yvy Pyte Y Jere (municipalité d'Aral Moreira, Mato Grosso do Sul, Brésil); 2) un autre à caractère propositionnel, suggère de penser la rencontre de la connaissance comme une conduite dans les pratiques de communication entre les mondes pour apprendre à apprendre sur l'alliance.

\section{MOTS-CLÉS}

Chamanisme Kaiowa; Rencontre de la conaissance; Communication entre mondes; Alliance.

\section{APRENDER A APRENDER ACERCA DE LA ALIANZA: COMUNICACIÓN ENTRE MUNDOSA PARTIR DEL ENCUENTRO CON UNA PAREJA DE CHAMANES KAIOWÁ}

\section{RESUMEN}

El artículo es una reflexión sobre experiencias de enseñanza-aprendizaje basadas en la práctica etnográfica multisituada (2012-ACTUAL) que incluyen los procesos formativos de un proyecto docente de pregrado que, como encuentro de saberes, se despliega en dos niveles: 1) uno de carácter descriptivo de algunas de las prácticas pedagógicas de una pareja de chamanes Kaiowá en tres cursos impartidos por ellos - dos por Valdomiro Flores en 2014 y 2016 y uno por Tereza Amarília Flores en 2018 así como en su territorio original, la reanudación de Guaiviry Yvy Pyte Y Jere (municipio de Aral Moreira, Mato Grosso do Sul, Brasil); 2) otra de carácter proposicional, sugiere pensar en el encuentro del conocimiento como una conducta en las prácticas comunicativas intermedias para aprender a aprender de la alianza.

\section{PALABRAS-CLAVE}

Chamanismo Kaiowá; Encuentro de saberes; Comunicación entre mundos; Alianza. 


\section{VALDOMIRO E TEREZA}

Figura 1 e 2. Tereza Amarília Flores e Valdomiro Flores no tekoha Guairivy, 2014.

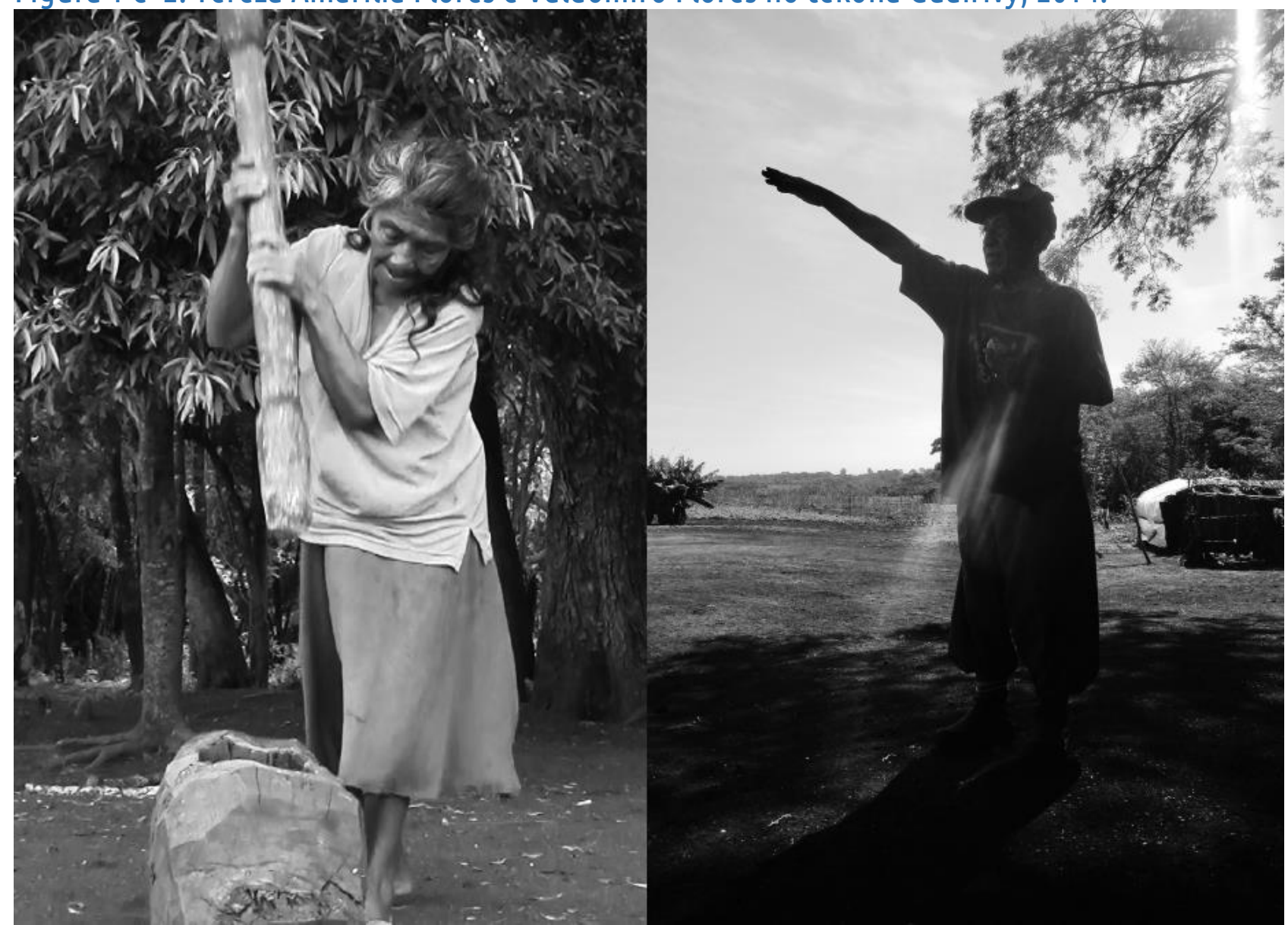

Fonte: Acervo do Programa de Extensão Imagem Canto Palavra no Território Guarani e Kaiowá (2014-ATUAL), coordenado pela autora.

Valdomiro Flores, Ava Apyka Renda Jurua, nasceu no que era, no início da década de 1930 do século XX, a recém criada Reserva Indígena de Amambai-MS². Filho do casal de xamãs Querina Vasquez e Antônio Flores, sobrinho do grande líder político e espiritual, Alberto Vasquez, foi casado com Tereza Amarília, com quem teve 10 filhos, cinco deles vivos e que trabalharam junto com Valdomiro, até o seu falecimento em 2017, nos roçados do Guaiviry, grande território onde viveram seus pais e os pais de sua esposa. Detém uma característica muito valorizada em sua mestria de rezador: ele o é por nascimento e não por um processo de formação e aprendizado vindos de outros rezadores. Manifestou, desde criança muito pequena, as habilidades para o diálogo com Ñanderu Guasu - o demiurgo criador das três terras - e qualidades como o mbarete (força espiritual) para a busca do aguyje (a perfeição). Outra característica de extremo valor em sua prática xamânica é que possui um

\footnotetext{
${ }^{2}$ De acordo com Chamorro (2015, p. 214): "reserva indígena criada pelo SPI. O Decreto Estadual 404/1915 criou a área com 3.600 ha, mas logo houve uma redução. Em 1926, o governo concedeu título definitivo de uma parte da área a um particular". Atualmente tem 2429,54 ha.
} 
vasto repertório dos cantos kotyhu e guahu, domínio do ritual ñembo'e puku (reza longa) para alçar os mais altos patamares da "terra lá de cima", especialmente realizados nas quintasfeiras de todas as semanas no tekoha e o domínio do ritual ñembo'e nimongarai (reza de nominação).

Tereza Amarília Flores (1938- ), Kuña Jeguaka Rory, é rezadora, agricultora, cantora, conhecedora e manipuladora de remédios com a utilização de plantas das matas do cerrado, do campo, do brejo e das beiras de rio, exímia preparadora do kaḡuĩ, bebida ritual Kaiowá feita de milho (branco e amarelo), batata, batata-doce, mandioca ou guavira, dos quais domina todas as etapas de preparação, bem como os cantos kotyhu ativadores de suas qualidades mágicas e espirituais. Mestra nos saberes e fazeres do povo Kaiowá, formou-se junto com seu companheiro, o Ñanderu Valdomiro Flores, e rezaram juntos até o falecimento deste no território do Guaiviry em 2017, onde viveram também os pais, irmãos, tios e tias, avôs e avós de Tereza, bem como toda uma extensa parentela em localidades distintas de um grande território do qual ela tem profundo domínio geográfico e histórico. Conhecedora de amplo repertório de cantos sagrados que incluem ñembo'e puku (a reza longa) e os cantos melodiosos guahu e kotyhu, além de amplo repertório de histórias-mitos, da memória de técnicas construtivas, artísticas e de conduta do "tempo antigo". Testemunhou o violento histórico de invasão dos territórios tradicionais e de luta pela sua retomada e atuou na resistência linguística, cultural, existencial dos povos Guarani e Kaiowá no Mato Grosso do Sul. Dona Tereza segue ativando os rituais de reza longa junto com os netos, os filhos e a parentela do tekoha retomado.

Como a grande maioria de seu povo, Valdomiro e Tereza trabalharam nas lavouras da região no período de formação das grandes fazendas (entre os anos de 1940 a 1970), processo para o qual colaboraram tanto com a força de trabalho quanto com a inteligência de suas formas de organização familiar e política que foram, muitas vezes, transpostas ao mundo do trabalho e usadas para negociar interesses econômicos alheios. Impossibilitados de praticar seu modo de vida profundamente espiritual - num Brasil que, com o arrefecimento da ditadura militar e seus efeitos nas políticas indigenistas, era cada vez mais violento na imposição da assimilação dos povos indígenas. Entre os anos de 1971 a 1991, o casal se exilou no Paraguai junto aos Paĩ Tavyterã, como é conhecido o povo Kaiowá do outro lado da fronteira. Ali viveram em diversos territórios onde Valdomiro e Tereza eram convidados a ficar em virtude da fama de seus poderes xamânicos. Em 1991, a convite do sobrinho de Valdomiro, Maurício Vasquez, então capitão da Reserva Amambai, voltaram ao Brasil e permaneceram na reserva até 2011, mas sempre idealizando voltar ao grande território do Tekoha Guaiviry. Valdomiro, Tereza e a esposa de Maurício rezavam em um grupo pequeno na reserva, composto de 13 pessoas no total, cujo objetivo maior era fortalecer Nísio Gomes e Odúlia Mendes que planejavam o processo de retomada. O 
reconhecimento de Valdomiro e Tereza como grandes autoridades não se restringe ao Tekoha Guaiviry, mas a todos esses locais onde residiram e outros mais distantes em países como Argentina e Uruguai para onde os remédios produzidos pelo casal já foram levados.

Lideranças espirituais comprometidas com a luta pela reconquista dos territórios tradicionais, sempre entenderam o xamanismo como forma de reconquista do diálogo com os parentes da "terra de cima" que também habitam e protegem os territórios nessa "terra em que vivemos", sendo essa reconquista o sentido maior para a retomada e a garantia da permanência nos territórios reocupados ${ }^{3}$. Voltar ao território originário é a possibilidade de retomada do teko e os cantos são elementos centrais na sua reativação, na medida em que são tecnologias de comunicação fundamentais para conversar com os/as jary (guardiões das coisas nas três terras), com os antepassados e antepassadas, bem como com Ñanderu Guasu e Ñandesy Guasu. Sem essas presenças um território não faz sentido. Além da retomada da comunicação com os seres espirituais que fazem a terra ser um território, o teko se faz também na convivência da família extensa, na produção dos alimentos nas roças, na sociabilidade doméstica nas rodas de chima e tereré bem como na sociabilidade ampliada dos rituais de dança e festa que ocupam o pátio entre as casas das lideranças e a casa de reza. Elementos da constituição de uma vida sagrada, temos por um lado os repertórios de cantos sagrados guahu e os kotyhu, celebrados com o kaḡuĩe, por outro lado, o ñembo'e puku, vivenciados com enlevo contemplativo no interior da casa de reza, sentados sobre o apyka e voltados para o norte.

\section{O POVO KAIOWÁ E A GUERRA PELA TERRA}

\footnotetext{
${ }^{3}$ Sobre o modo como Valdomiro e Tereza concebem as três terras, suas interconexões e seus espelhamentos, ver: "A terra originária, as três terras, a guerra pela terra" (FLORES; FLORES; OLIVEIRA, 2020, p. 448-465).
} 
Figura 3. Elizeu Lopes Kaiowá em protesto no qual 5.000 cruzes são fixadas na Esplanada dos Ministérios em Brasília, outubro de 2012.

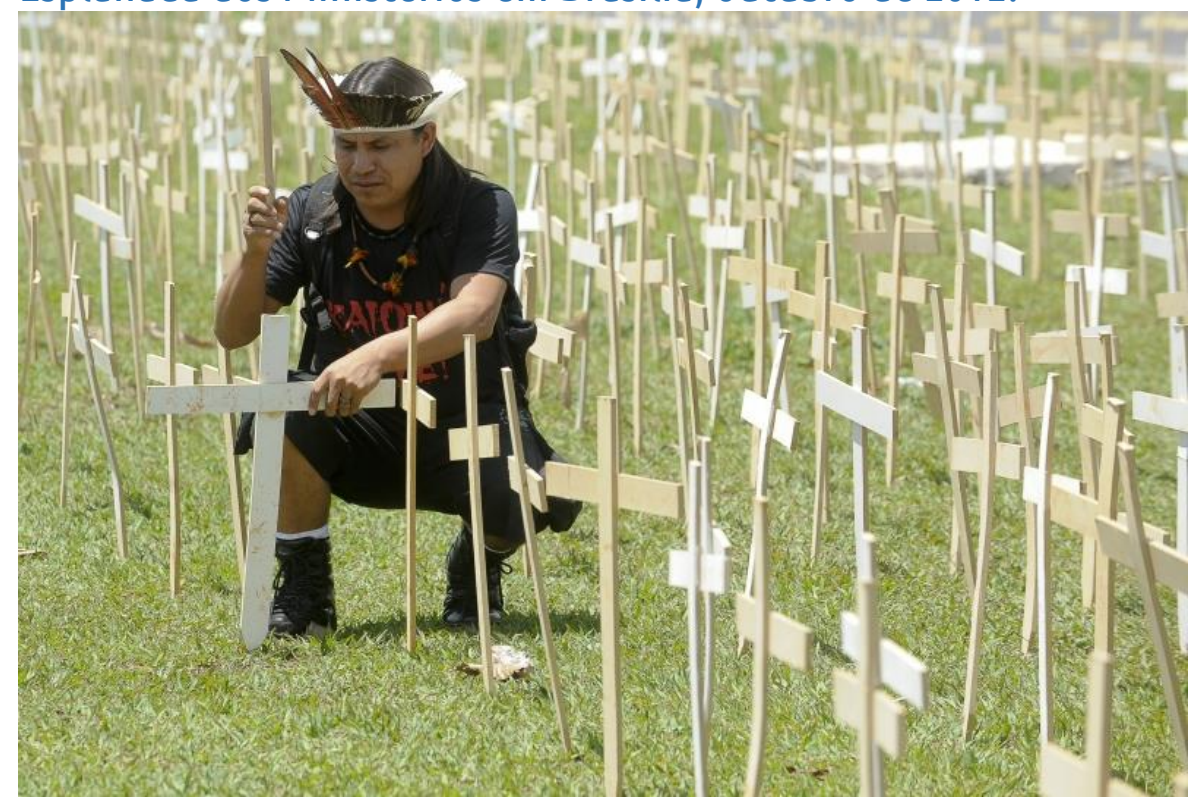

Fonte: $\underline{w w w . e c o d e b a t e . c o m . b r}$.

Valdomiro Flores costumava sempre afirmar: "a guerra do Paraguai nunca acabou" (2014; 2016). Com essa frase introduzia um testemunho histórico detalhado e contundente sobre o genocídio de seu povo ao longo do século XX, do qual não se via como vítima, mas como um guerreiro sobrevivente na defesa de um mundo e de uma causa: rezar para o mundo não acabar. Em outros termos, intelectuais de formação ocidental têm nomeado os processos de gestão estratégica da morte como uma necropolítica (MBEMBE, 2016) com a permanência de quadros de guerra (BUTLER, 2015) que definem quais vidas são as que contam e quais as que não contam. Para Butler (2015, p.13), em tais guerras, "se certas vidas não são qualificadas como vidas de acordo com certos enquadramentos epistemológicos, então essas vidas nunca serão vividas nem perdidas no sentido pleno dessas palavras". As reflexões em termos da necropolítica explicam que as várias maneiras de matar são implantadas no interesse da destruição máxima de pessoas e da criação de "mundos de morte", formas novas e únicas da existência social, nas quais vastas populações são submetidas a condições de vida que thes conferem o status de "mortos-vivos" em experimentos concentracionários baseados numa imaginação limitada de fronteira e nos quais a paz toma feições de uma guerra sem fim (MBEMBE, 2016).

Nessa senda, Ailton Krenak (2019) fornece outra importante chave interpretativa: os povos indígenas das Américas são grandes especialistas no fim do mundo já que seus mundos vêm acabando há muitos séculos. O objeto dessa guerra - protagonizada de um lado pelos índios e do outro por poderes econômicos atualmente sem rosto do capital transnacional em aliança com o Estado - é a terra. A guerra pela terra envolve dois aspectos cruciais, conformando um dispositivo, um de natureza jurídica e outro de natureza 
comunicacional. Raquel Rolnik (2015) os caracteriza como: 1) insegurança jurídica da posse da terra; 2) a estigmatização, a estereotipia, a fabulação de quem são aqueles e aquelas que habitam os territórios para que sejam desconsiderados ou removidos ao bel prazer do capital sob o comando do Estado. Na guerra histórica de longa duração pela terra em Mato Grosso do Sul ${ }^{4}$ - onde se localizam os territórios tradicionais Kaiowá e Guarani - tal dispositivo foi construído a partir tanto de um arcabouço de leis e políticas públicas quanto de um conjunto de esforços midiáticos e pedagógicos (como é o caso dos livros didáticos no Brasil) para caracterizar os indígenas como selvagens, preguiçosos, falsos e, por fim, inexistentes (FREIRE, 2000; GRUPIONI, 2000; MELATTI, 2007; CUNHA, 2012; GOMES, 2012).

Historicamente, as grandes frentes de colonização da região são marcadas por dois grandes ciclos extrativistas. A exploração da erva-mate, naturalmente abundante, se deu com a criação da Companhia Matte Larangeira pelo decreto imperial no 8 799, de 9 de dezembro de 1882 que concedeu cerca de 5.000 hectares de terras a um particular, Tomás Larangeira. Essa frente extrativista utilizou basicamente da mão de obra indígena em condições de escravidão e semi-escravidão. No contexto da Marcha para o Oeste, esforços sistemáticos de povoação se deram com colonos oriundos do sul do Brasil, buscando promover a ocupação do território. Apesar da guerra entre a Tríplice Aliança e o Paraguai ter terminado oficialmente em 1870, havia ainda um fluxo intenso de migrações de paraguaios e correntinos para o Brasil, e porções de território que precisavam ser "protegidas" e "bem ocupadas", e foram então criadas as colônias agrícolas. Este foi sucedido por outro extenso período extrativismo das matas nativas que promoveu a destruição massiva do bioma cerrado, característico na região. A madeira foi a commodity que capitaneou tal exploração.

Ao lado desses ciclos econômicos, em 1910, sob inspiração positivista e dos imaginários republicanos, o Estado brasileiro cria um órgão especial para cuidar da política indigenista, o Serviço de Proteção aos Índios (SPI) ${ }^{5}$, que teria por objetivo "proteger" os indígenas da aculturação e destruição. A grande ação deste órgão na região foi criar uma política de reservamento de terras, construindo fronteiras e territórios específicos para os

\footnotetext{
${ }^{4}$ As colaborações bibliográficas para tecer esse pequeno resumo histórico vieram de diversas referências. O antropólogo Levi Pereira (2016), ao apresentar os módulos de organização social e da estrutura política, assim como os aspectos fundamentais para humanização do espaço, traz informações significativas sobre a história de contato. O violento processo de ocupação dos territórios indígenas tradicionais pelas frentes agropastoris nas últimas décadas do século XX é objeto das pesquisas do historiador Antônio Jacó Brand (1993; 1997), especialmente dedicadas ao modo como a estratégia do esparramo (sarambi) desmontou as lógicas de organização social e dinâmicas de parentesco que sustentam o teko e o tekoha para dar lugar à situação de confinamento territorial nas reservas. Em Chamorro (2015) há um esforço didático de sistematização de todo o processo histórico de contato na região (desde o séc. XVI até o séc. XXI). De forma detalhada, o processo de expropriação e despejos bem como o sarambi dos Guarani e Kaiowá em MS está descrito no segundo capítulo da tese de doutorado de Benites (2014).
}

${ }^{5}$ O SPI tornou-se Fundação Nacional do Índio (FUNAI) em 1967. 
indígenas viverem sob a promessa de oferecer boas condições de saúde, alimentação e educação. Entre 1910 e 1928 foram criadas oito reservas, que não necessariamente coincidiam com os territórios tradicionais e com tudo o que a relação com a terra representa para os povos Kaiowá e Guarani.

A partir dos anos 1950 sistematizaram-se os esforços governamentais e de grandes proprietários para a implantação de uma agropecuária industrial para exportação. É nesse período que se conformam as grandes fazendas de monocultura nas quais a força motriz vem da mão de obra indígena, tanto aquela das reservas quanto a dos indígenas considerados "desaldeados". Nas matas ciliares, aquelas que recobrem os leitos de rios e que são, ainda nos dias de hoje, testemunhas solitárias da vegetação espessa do cerrado - o mato grosso (ka'aguy guasu) típico que nomeia a região - vários grupos familiares Kaiowá e Guarani seguiram, às escondidas, mantendo, reproduzindo e fazendo circular seus conhecimentos e formas tradicionais de viver, construindo uma resistência cultural, linguística, religiosa e existencial sem precedentes num entorno hostil e genocida.

Mas a destruição e perseguição aos modos de vida tradicionais intensificada durante os anos de chumbo da ditadura militar forjaram, no final dos anos 1970, em sintonia com toda uma movimentação e organização dos diversos povos indígenas na América do Sul, uma virada importante. Organizados sob a forma de grandes assembléias conhecidas como Aty Guasu Guarani-Kaiowa ${ }^{6}$, iniciam um conjunto de ações de retorno aos territórios tradicionais deliberadas comunitariamente e chamadas de retomadas. Com base na memória dos anciãos e das anciãs e fortalecidos pela ativação dos cantos-rezas em rituais a um só tempo políticos e sagrados, irrompem de peito aberto nos territórios movidos pelo sonho de reviver o teko tradicional e deixar para trás a vida precária das reservas ${ }^{7}$.

\footnotetext{
${ }^{6}$ Kaiowá e Guarani são povos distintos mas que têm uma língua próxima e uma união política em torno do conflito fundiário grave que enfrentam e na luta por fazer valer o direito aos seus territórios originários, garantido pela Constituição Brasileira de 1988. Ambos os povos são falantes da língua Guarani (que tem inúmeras variações em suas modulações ativas na vida dos tekoha e das reservas) da família linguística tupi-guarani, do tronco tupi e coabitam, hoje, um território próximo e, por vezes, comum no sul do estado do MS, totalizando cerca de 55 mil pessoas. A literatura antropológica tem definido, especialmente a partir do trabalho de Schaden (1962), que os povos guarani se subdividem em três grupos: Ñandeva, Mbya e Kaiowa. Em MS, os Ñandeva se autodenominam também de Guarani, sendo as duas denominações utilizadas indistintamente. Guaiviry Yvy Pyte Y Jere, território originário de Tereza e Valdomiro, é um dos tekoha Kaiowá no sul de MS, fazendo parte desse movimento de auto-demarcação dos territórios tradicionais - conhecido como retomada de terras - iniciado em maior escala a partir dos anos de 1980. Foi reocupado em 2011 e ocasionou o brutal assassinato da liderança que conduzia os grupos familiares, o Cacique Nísio Gomes. Atualmente abriga cerca de 40 famílias e 300 pessoas que seguem na luta cotidiana de afirmação do teko Kaiowá (o modo tradicional de viver) e na defesa do território contra os interesses econômicos do agronegócio.
}

${ }^{7}$ Sobre a organização dos Aty Guasu ver especialmente Almeida (2001) que relata a partir de pesquisa etnográfica a criação do Projeto Kaiowá Ñandeva (PKN) e dos Aty Guasu. As teses de Pimentel (2012) e Benites (2014) dedicam-se, a partir de diferentes problemas antropológicos e 


\section{AS DIFICULDADES DO ENCONTRO DE MUNDOS E SABERES}

Figura 4. Tereza Amarília Flores e suas assistentes/tradutoras, Luíza Flores (à esquerda) e Johnn Nara Gomes (à direita), 2018.

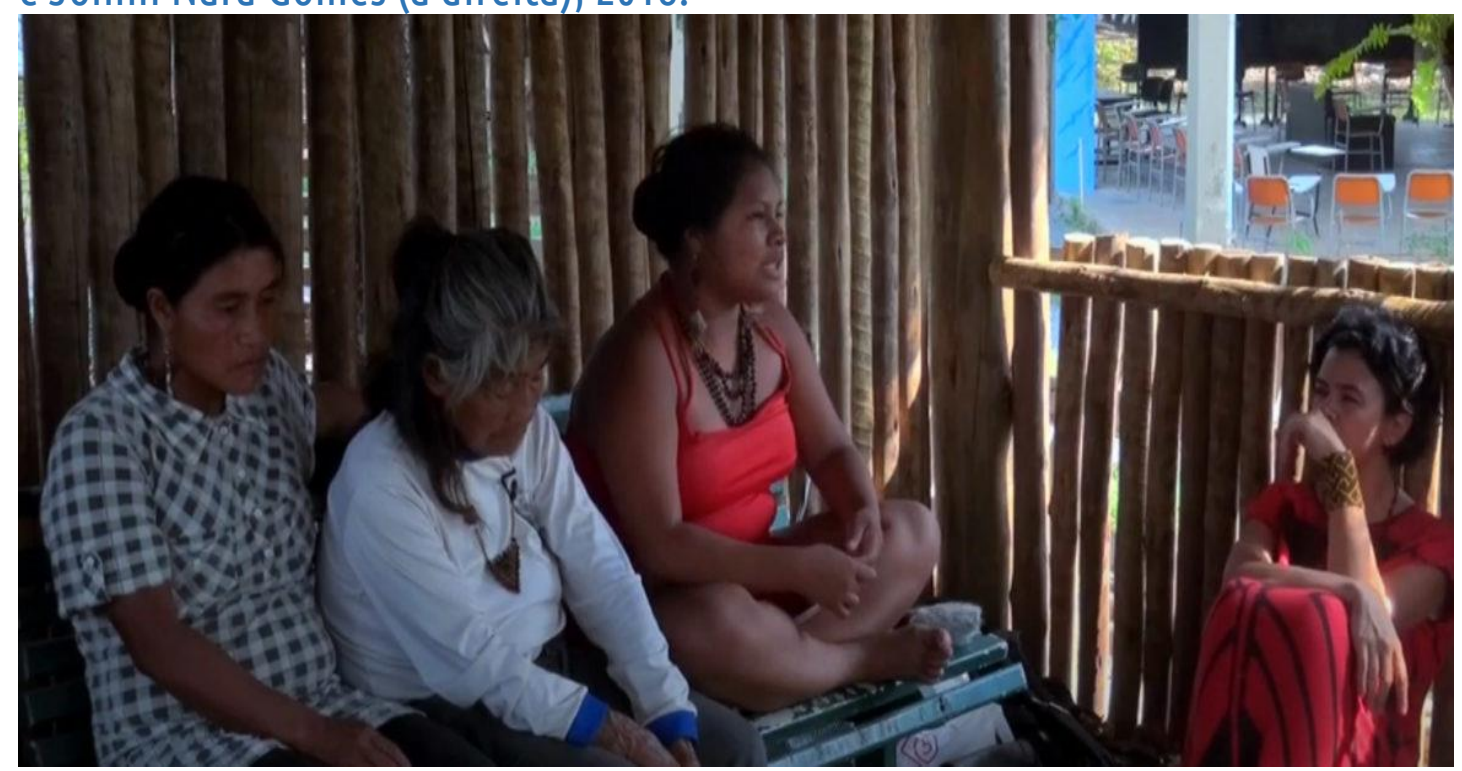

Fonte: $\underline{w w w . s a b e r e s t r a d i c i o n a i s . o r g . b r}$.

Valdomiro Flores ditou dois cursos na universidade - Cosmociência Kaiowá (2014) e Ojohu Ñe'é/Mbopaje Ñe'ē ou Encontrar a Palavra/Encantar a Palavra (2016); Tereza Amarília ditou o curso Políticas da Terra Kaiowá (2018) . Valdomiro e Tereza só falam a língua Guarani. Não estão autorizados a falar português. Esse preceito faz parte de sua disciplina para as práticas xamânicas. As aulas foram ditadas nessa língua e havia tradução consecutiva por assistentes bilíngues do mestre e da mestra. Os assistentes falam português como segunda língua, mas só a aprenderam ao frequentarem a escola intercultural. Como educadores, atuando na universidade ou no Tekoha Guaiviry, Valdomiro e Tereza sempre falaram de uma aliança possível entre nós. Aliança. "Ahayhu ichupe kuera", Valdomiro dizia, e batia no próprio peito. "Eu os amo", dizia a Genito que iria traduzi-lo em seguida, apontando para os/as estudantes. Amor. De que aliança Valdomiro e Tereza estavam falando?

A aluna Beatriz Cordeiro Lopes discorreu sobre a dificuldade de codificar essa e outras falas do mestre em seu trabalho final da disciplina ministrada por Valdomiro e seus assistentes/aprendizes Daniel Lemes Vasques e Genito Gomes em 2016:

fontes de pesquisa, a contar a história dos Aty Guasu. Enquanto o primeiro os analisa sob o prisma da cosmopolítica, o segundo se dedica mais especificamente à questão territorial e ao tema da friç̧ão interétnica, com forte acento no trabalho de campo com os anciãos das retomadas de Jaguapiré, Potrero Guasu, Kurusu Amba e Ypo'i.

${ }^{8}$ Formação Transversal em Saberes Tradicionais da Universidade Federal de Minas Gerais (2014ATUAL). www.saberestradicionais.org.br. 
Fiz poucos registros e anotações das aulas, nessa minha estranha e escusa relação com a palavra - precisamente o tema que dá nome à disciplina. Umas poucas citações dão conta das primeiras aulas, em sala, mas a maior parte das sabedorias pronunciadas pelos mestres, seus cantos, seus corpos, suas expressões, suas vestes e suas cores quis manter em meu coração - como se, assim, não revestidas pela formalidade engessante do registro, mantivessem melhor a espontaneidade e a pulsação da experiência viva. Minha dificuldade em lidar com o registro, e em especial com a palavra, fez com que várias das minhas referências e lembranças se confundissem. Muitas observações também se perderam em meio ao torvelinho político-espiritual desses tempos sombrios. Ficaram, principalmente, as impressões sensitivas e emotivas, já imiscuídas a reflexões mais ou menos relacionadas aos temas. São elas, impressões e reflexões, que tento perfilar aqui, neste exercício de conciliação com a palavra.

A dificuldade de compreensão também se instalou quando do primeiro curso ministrado por Valdomiro em 2014: ele pediu que não fizéssemos chamada para que estudantes viessem às aulas de forma voluntária e de "coração limpo". Caso contrário, melhor não virem. Ao final da disciplina, muitos alunos e muitas alunas confessaram-se em dúvida sobre "a verdade" de seus sentimentos e desejos em presença do mestre e da cosmociência Kaiowá.

Tereza, após contar em sua primeira aula toda a história violenta do contato e as inúmeras perdas pessoais por ela vivenciadas - da terra, das matas, dos roçados grandes, dos remédios, do direito de ir e vir, de animais que não existem mais, dos parentes que adoeceram e morreram bem como dos que foram assassinados - enfatizou com severidade que, ainda assim, ela e sua família rezam para o mundo não acabar: "porque sem a reza estaríamos todos condenados à morte". Uma aluna então perguntou: "mas vocês rezam só por vocês ou rezam pelos brancos também?". A pergunta vinha rodeada de suspense e apreensão. Parecia que a resposta evidente seria que: "só pelos Kaiowá", afinal o que a motivaria rezar pelos brancos perpetradores de tantas atrocidades que Tereza testemunhou, vivenciou e acabara de relatar? A resposta veio com mais ênfase ainda: "nós rezamos pelo mundo inteiro: brancos, kaiowá, indígenas de outras nações, negros. Se não rezarmos, a morte recairá impiedosamente sobre todas as pessoas de todas as nações no mundo inteiro. É isso que os brancos precisam entender. Nós fazemos a nossa parte, eles fazem a deles e poderemos viver em paz".

Meu primeiro encontro com Valdomiro e Tereza foi permeado por tensões. Aconteceu no tekoha Guaiviry em 2013, na minha segunda viagem ao MS ${ }^{9}$. Naquela ocasião, após um pedido muito formal de licença do cacique Genito, liderança política do tekoha e de Valmir Gonçalves Cabreira que me ciceroneava naqueles tempos, fomos à casa do casal. Essa etiqueta me deixava bem apreensiva quanto ao modo de me comportar em presença dele e

\footnotetext{
${ }^{9}$ Minha relação com os Kaiowá começou em 2012, durante o Festival de Inverno da UFMG, quando o aprendiz de xamã Valmir Gonçalves Cabreira narrou o assassinato de Nísio Gomes que ele testemunhou, bem como da presença dos Bro MC's Rap Indígena.
} 
dela. Nos sentamos no pátio da casa principal, no banco que gentilmente trouxeram para nós. Genito foi quem explicou quem eu era: "professora de Minas Gerais que queria conhecer mais do jeito de viver dos ava e das kuñague e ajudar na nossa luta". Era início do ano. Tempo das chuvas. Valdomiro iniciou sua explicação contando das aldeias da "terra lá de cima", apontou, no alto, as diversas direções e contava sobre quem eram os seus e as suas habitantes. Quando chegou ao chamado "Rehimiento 13", contou-nos que era um lugar onde viviam os povos-raio que conformavam um grande exército de guerreiros e que, muitas vezes, os raios que alcançam a terra são flechas lançadas por esse povo para proteger os Kaiowá dos famigerados brancos. Nesse momento, caiu um raio no tekoha. Minha caneta foi ao chão e o coração acelerou. Valdomiro encerrou a entrevista sem mais e foi para dentro de casa com Tereza. Pensei: será que minhas intenções aqui são verdadeiras e puras? Pensei: ele e ela nunca mais vão conversar comigo. Depois disso, muitas entrevistas vieram e o nosso trabalho em colaboração prosseguiu até o falecimento de Valdomiro e segue até os dias de hoje com Tereza ${ }^{10}$.

Em nossos encontros, no território da universidade ou do Guaiviry Yvy Pyte Y Jere, o casal sempre enfatizou as diferenças que cercam o jeito de ser dos ava e o jeito dos karaí viverem. Referiam-se com saudade ao tempo antigo (yma guare) do bom viver (teko porã/teko joja) - antes do contato, antes dos sarambipa (o espalhamento de rezadores e rezadoras e de seus grupos familiares) nos quais as regras dos kaiowá valiam e que eles gestionavam a vida e o território segundo seu jeito sagrado que eles descreviam como "natural e simples". Se pudessem escolher, não gostariam que seus antepassados tivessem admitido a presença dos karaí nos seus territórios pois há uma incompatibilidade incontornável entre os modos de vida de ambos.

Os Kaiowá podem até aprender o português, o jeito de vestir e as etiquetas dos brancos, mas não se tornam brancos. Para os Kaiowá eles são o segundo grupo de parentes na relação com os criadores do cosmos, logo após os guardiães (jary) de tudo o que existe

10 As ações realizadas em parceria com o casal se deram no âmbito do Programa de Extensão Imagem Canto Palavra nos Territórios Guarani Kaiowá (2014-ATUAL) com financiamento do edital Proext/MEC; Rumos Itaú Cultural 2018-2019; do Projeto de Pesquisa Regimes de Conhecimento e Formas de Vida na Universidade (2016-2020) com financiamento da Prograd-UFMG, Edital Universal Fapemig 2018; do Programa de Formação Transversal em Saberes Tradicionais da UFMG; e do Projeto Tee | Descendentes com financiamento do Rumos Itaú Cultural 2018-2019. São seis filmes produzidos (4 curtas-metragens, 1 longa-metragem e mais um longa em preparação) que já circularam em mostras nacionais e internacionais tendo recebido reconhecimento e diversos prêmios; dois livros (disponíveis em formato impresso e digital), o site do Aty Guasu (http://atyguasu.blogspot.com/) e mais um site (em preparação) da Associação Añetete de Guaviry. Além disso, o projeto em artes visuais Bordados pela Paz Guarani e Kaiowá Brasil (https://mbasic.facebook.com/bordadospelapazguaranikaiowabrasil) que, junto com o curta Ava Marangatu/Ser Sagrado, participou da exposição How To Talk With Birds, Threes, Fish, Snakes, Bulls and Lions no Hamburger Bahnhof Museum em Berlim (2018-2019), dentre outras nove ações públicas no Brasil e fora. 
nos mundos daqui, de baixo e de cima. As relações de parentesco próximas dos Kaiowá com o mundo das divindades são evidências dessa incompatibilidade. Valdomiro e Tereza afirmam essa condição rememorando um dos versos poéticos da reza longa que fala da criação do mundo: "Ñanderu ha Ñandesy yvy mbohesapa hare niko ore", ou, "Quando Ñanderu e Ñandesy iluminaram a terra éramos só nós". É essa antiguidade e proximidade familiar que faz com que os Kaiowá sejam um povo sagrado e sejam os portadores das rezas primordiais com as quais os mundos foram feitos, já que os antepassados e as antepassadas dos que vivem agora foram testemunhos vivos da criação.

\section{KONGOE E YNAMBU PYTÃ: TRADUÇÃO MÍTICA DA IMPOSSIBILIDADE DO ENCONTRO}

Figura 5. Desenho de verso do Kotyhu do Kongoe, de Juliana Flores.

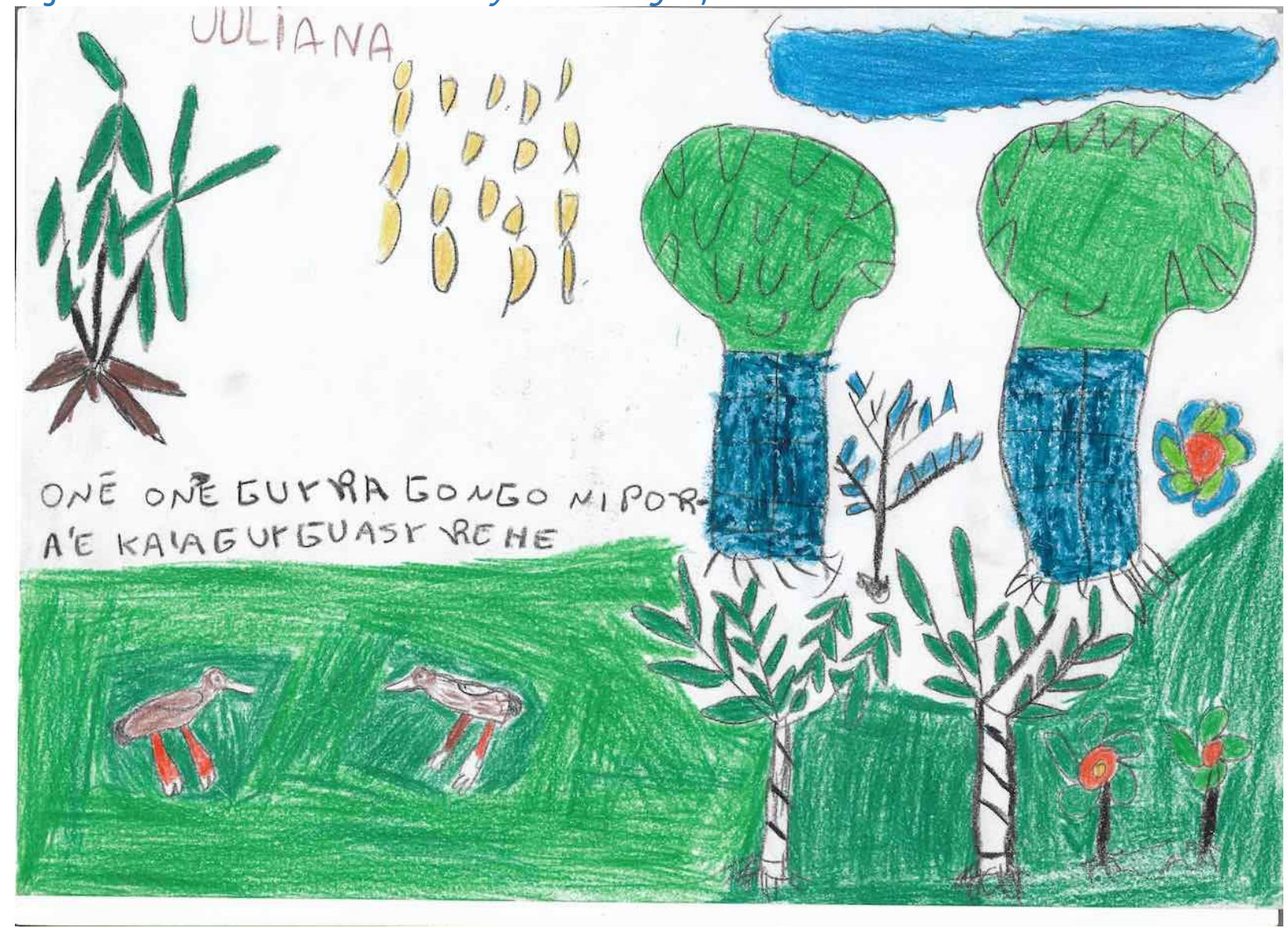

Fonte: acervo de pesquisa da autora.

Não raro, Valdomiro e Tereza elaboravam esse mau encontro histórico no tempo mítico, evocando as figuras sagradas dos pássaros Kongoe (Crypturellus undulatus) e Ynambu Pytã (Crypturellus tataupa), dois pássaros do cerrado que vivem uma história de amor impossível. Kongoe é conhecido como jaó em português, e Ynambu Pytã, também chamado de Guyrapopĩ é a perdiz. O primeiro vive nas matas e o segundo nos campos abertos. 
Segundo a versão mítica contada pelos xamãs, os dois pássaros eram irmãos e filhos diretos de Nanderu.

Um dia, enquanto Ñanderu já se preparava para ir ao alto, na terra de cima, pediu que Kongoe e Ynambu fossem buscar água, mas que não se demorassem porque já era quase dia e a luz já ia chegar para levá-lo. Eles não cumpriram o determinado pelo pai. Foram e tardaram muito em regressar, então a luz veio e levou Ñanderu para o alto e os dois ficaram para trás, tornando-se então habitantes dessa terra na qual nós vivemos. Os dois pássaros vivendo aqui se apaixonaram, contra a vontade do pai, pois eram irmãos (ou irmãs). Mesmo assim tentam ficar juntos, mas Ñanderu os separa colocando Kongoe para viver no mato e Ynambu Pytã para viver no campo. Com isso Ñanderu tenta romper a impulsividade do amor entre eles, restando-lhes apenas a comunicação à distância (quando o pássaro Ynambu canta no campo Kongoe responde na mata, este comportamento é observável até os dias de hoje). Ainda assim os dois pássaros irmãos (ou irmãs) tentam viver juntos e Ynambu vai viver com Kongoe na mata, mas ele não consegue se adaptar ao seu território e ao seu modo de vida. A história da separação é de profunda tristeza, envolve muitas idas e vindas, contando com vários outros animais que tentam ajudar o casal a se reconciliar ou a intercambiar mensagens. Essa história é também cantada, estabelecendo articulações de uma grande cadeia mítico-zoológica que envolve tanto o conhecimento descritivo do comportamento de cada um dos animais evocados (Kongoe, Ynambu, Coruja, Tangará, Macaco, Papagaio, e o pássaro Guatytyu) quanto as relações entre eles, trazendo a possibilidade de suas características serem tanto afirmadas quanto incorporadas nos participantes da roda já que o canto é dançado. Ao final, essa cadeia compõe a raiz de um canto de grande valor classificado na comunidade como Kotyhu Yta ${ }^{11}$ - pois tem poderes mágicos reconhecidos, desejados e temidos de despertar a paixão quando evocado nas rodas coletivas de dança ou mesmo quando utilizados em segredo o que, em porções exatas, "alcançam (ohupyty) uma pessoa". Apresento um pequeno excerto do canto e sua tradução ${ }^{12}$ :

Ynambu Pytã he'i: "Ahase nga'uma che ave nde rekoha" Diz o Ynambu: "Tomara que se realize meu desejo de ir também no seu lugar" Kongoe he'i jevy: "Jahata che ndive jahata che ndive jahecha haguã che rekoharã rire/che rekoha va'e che rekoha va'eee Kongoe responde: Vamos comigo, vamos comigo, para vermos, depois, o meu lugar/meu lugar é assim meu lugar é assim

\footnotetext{
${ }^{11}$ Informações repassadas por Daniel Lemes Vasquez e Johnn Nara Gomes, aprendizes e tradutores de Valdomiro e Tereza.

${ }^{12}$ Transcrições e traduções de Luciana de Oliveira, cantadas/contadas por Daniel Lemes Vasques.
} 
Então perdiz vai por um tempo viver com ele no mato e Kongoe fica muito feliz: "Avy'a pave va'e chevy"

"Sou infinitamente feliz por ter você assim comigo". Kongoe mostra-lhe todos os detalhes de onde vive e o convida para ficar para sempre, cantando:

"Javy'a che rekoha va'e javy'a voi che rekoha va'e".

"Somos felizes no meu lugar que é assim, somos felizes de verdade no meu lugar que é assim.

Mas perdiz não gosta do mato e diz que sente muito, que precisa ir embora e acaba voltando para o campo, não obstante Kongoé implore chorando para que ele fique e canta: "Ko'anga katu apyta che añomi, ko'anga katu apyta che añomi". "Agora só resta eu bem sozinho, agora só resta eu bem sozinho".

No tekoha, a mitopoética e sua ativação pelo canto são utilizadas para ensinar sobre as interdições nas trocas matrimoniais e tabus sexuais, mas os xamãs também a usavam para elaborar o tempo histórico: os conflitos de terra no MS e a relação com o mundo dos brancos coloca o povo Kaiowá e "os fazendeiros" nesse lugar mítico que, como tempo do sempre, se reatualiza no presente e, por isso, não conseguem viver juntos pois seus modos de vida, seus territórios e seus mundos são incompatíveis. O canto, nas rodas, obedece à lógica ojeropapa, uma espécie de alternância entre cantores-puxadores da roda, que tem a característica de uma disputa, mas que gera um movimento espiralar crescente ativador das suas qualidades mágicas de troca e agenciamento da perspectiva. Assim, não somente é uma metáfora ou representação, mas um dispositivo prático de experiência da política do fazer comum que põe em ação os mundos como também da política de fazer gente, afirmando e ampliando o controle da pessoa sobre sua existência ao conquistar controle sobre as alternâncias da perspectiva. O Kotyhu Yta também pode ser nomeado como jahe'o, araguaju ou não ser nomeado. Nesse último caso, um mais velho simplesmente diz: "okotyhu vy'a mbarete" ou "okotyhu ojeropapa guasu", respectivamente, "vamos dançar o kotyhu forte" ou "vamos dançar o kotyhu num grande movimento de ojeropapa". Esse canto, muito valoroso para os Kaiowá de Guaiviry, evoca a força de Pa'i Tambeju - um dos jary, parente dos Kaiowá, que guarda o amor, as doenças, a cura e a fertilidade, associado com os eventos do mês de agosto e a floração da árvore tajy (ipê) - e se divide em cinco partes: 1) Ynambu Pytã e Kongoe Guahu; 2) Tangara Guahu 3) Guatytyu Guahu 4) Ka'i Guahu 5) Kavure Guahu. Juntas elas formam uma espécie de "raíz do canto", sem o seu domínio, o kotyhu "fica sem gosto"13.

\footnotetext{
${ }^{13}$ Guahu e kotyhu são modalidades de cantos do patrimônio imaterial Kaiowá. Os guahu são cantos dos animais míticos e juntos perfazem um grande conjunto de formas poéticas que descrevem e
} 


\section{ÑEMBo'E PUKU}

Figura 6. Cena da Reza Longa. Autoria coletiva.

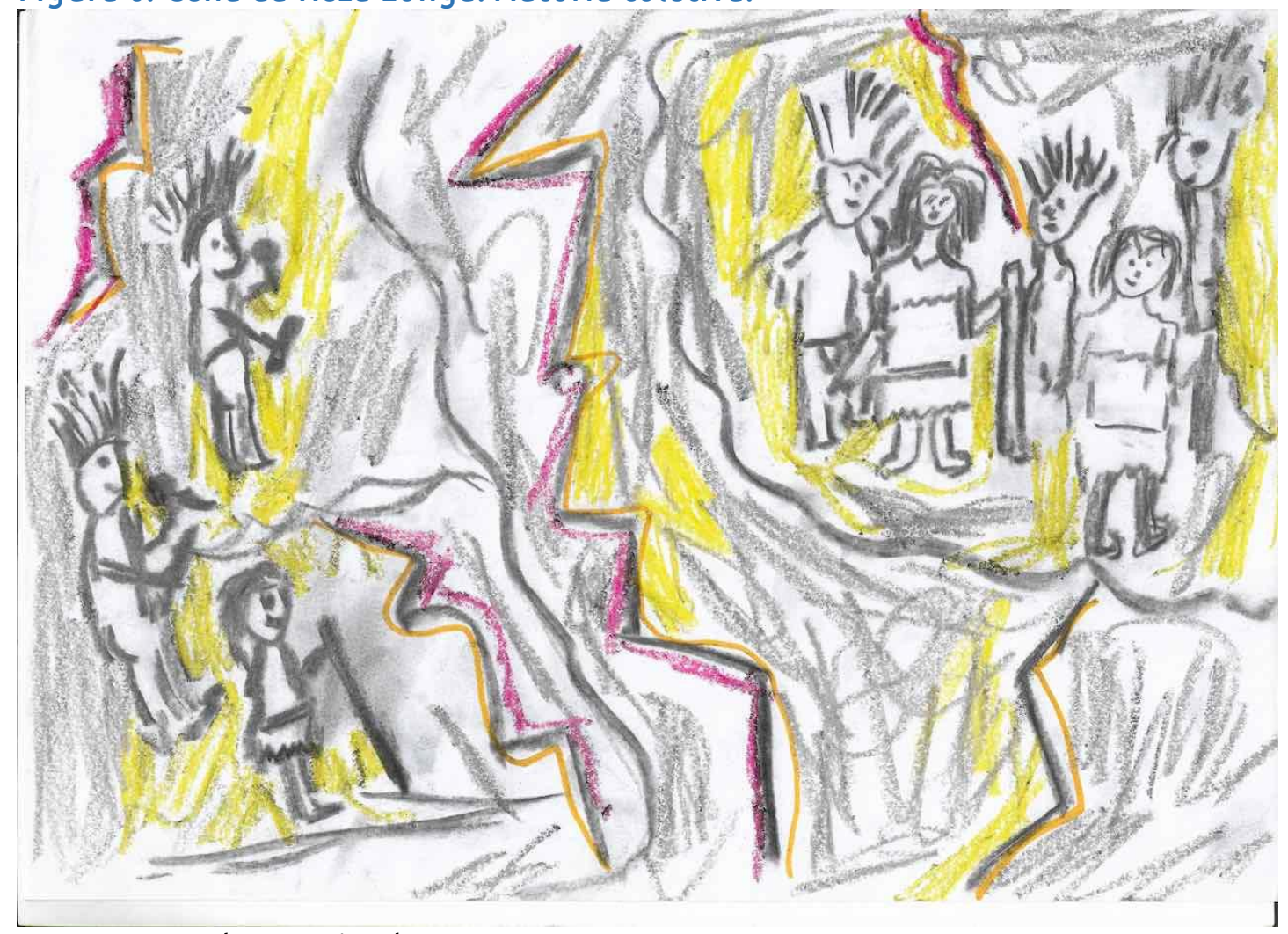

Fonte: acervo de pesquisa da autora.

Valdomiro e Tereza queriam ensinar em Belo Horizonte, assim como o fazem no tekoha, por meio do ritual da reza longa (ñembo'e puku). Nunca quiseram realizar nenhuma ação ritual em sala de aula, nem mesmo um canto em caráter demonstrativo como apresentação ou como uma benção para os presentes. Não poucas vezes Valdomiro criticou a arquitetura da sala de aula: um lugar onde a força espiritual rebate nas paredes e não pode circular. Tereza, que veio depois dele, sempre pediu espaços abertos, perto da mata da

ativam as formas animais no mundo atual no qual vivemos. Os kotyhu são cantos leves e que tematizam as relações e interações dos homens e mulheres, mas que podem também se relacionar com as qualidades de animais e de plantas. Diversos trabalhos no campo da etnomusicologia e da etnologia têm atestado o valor patrimonial, estético e político dos cantos nas experiências de diversas nações indígenas. No caso do povo Kaiowá, há vários esforços tanto de catalogação quanto de classificação dos repertórios mencionados. Algumas classificações correntes separam os ñembo'e, rezas ou cantos xamânicos, como cantos religiosos, em oposição aos guahu e kotyhu como cantos profanos já que evocados na constituição de espaços de sociabilidade restritos à humanidade dos humanos (BENITES, 2014). Izaque João (2011) classifica os guahu e kotyhu como cantos de diversão. Montardo (2006) contestou essa divisão já que os guahu e kotyhu são também cantos ritualísticos. Graciela Chamorro (2008) chama os guahu de "cantos lamentosos" e os kotyhu de "cantos de encontro". Em contraponto, o projeto de documentação colaborativa, organizado por Rodgers et al (2017), os classifica como "cantos míticos" e "cantos líricos", respectivamente. No tekoha diversas formas de classificação e explicação do poder dos cantos são também ativadas, discutidas e explicadas. No artigo, priorizei mostrar uma dessas classificações ativas na vida comunitária de Valdomiro e Tereza que conta, inclusive, com seu respaldo. 
universidade, para proferir seus ensinamentos. Valdomiro queria realizar a reza longa com a presença de todos os alunos e de todas as alunas matriculados em seu curso. Isso significaria atravessar a noite, proferindo os cantos sagrados em jornada até os patamares mais elevados da "terra lá de cima". Não se pode dormir. Não se deve comer carne no dia da reza, nem ter relações sexuais, é preciso preservar o espírito calmo, não sentir raiva. É preciso escutar a história que a reza guarda, é preciso caminhar junto com os rezadores, é preciso ter disciplina e cumprir preceitos para se alcançar a perfeição na reza, ou como dizem seus praticantes, para a "reza alcançar a pessoa". "Todo o conhecimento Kaiowá está na reza", afirmavam veementemente Valdomiro e Tereza em seus cursos.

O ritual da reza longa acontece no tekoha Guaiviry todas as quintas-feiras. Começa ao entardecer e termina ao amanhecer do dia seguinte. Envolve uma longa caminhada cosmológica cheia de perigos e de belezas, relações com os espíritos dos e das ancestrais, com uma miríade de entidades sagradas (em seus princípios masculinos e femininos), espíritos dos animais e de plantas, além dos espíritos dos vivos que se deslocam até lá posições passíveis de se transformarem umas nas outras. Esse "lá" é chamado terra de cima tradução preferida por aprendizes de Valdomiro e Tereza em lugar de céu ou celeste conformado em quinze patamares e infinitos caminhos, bifurcações, salas, lugares, paisagens sem coordenadas geográficas e temporais estáveis. Segundo os xamãs tudo o que existe aqui, existe lá.

Entre os jovens do tekoha, a reza longa, cantada à maneira de ondas de brilho que explodem em intensidades diversas, provoca conversações em torno dos ensinamentos de Valdomiro e Tereza bem como sobre os seus próprios caminhos de aprendizagem e seus diferentes níveis de competência para a viagem cosmológica nela implicada (que exige habilidades como força, leveza e perseverança criadas a partir da observação rígida dos preceitos e de práticas cotidianas que impulsionam a experiência do teko: o modo natural e verdadeiro de viver Kaiowá). O entendimento dos versos melodiosos e provocadores de muita curiosidade e ambição nos jovens é por vezes bastante difícil, mesmo para os falantes do guarani como língua materna, pois eles são cantados por debaixo da língua ("opurahei hina kũ guype"). Além de fazer parte da musicalidade kaiowá, os aprendizes entendem essa ação como uma estratégia pedagógica dos xamãs para que eles levem mais tempo para aprender, o que pode tornar seu aprendizado mais efetivo.

Valdomiro sustenta o canto-reza ñembo'e por muito tempo. São horas de recitação cantada e solene dos versos sagrados. Por vezes um mesmo verso é modulado com variações sutis por mais de uma hora. As variações são da ordem da intensidade: enquanto o ritmo do mbaraka permanece constante, decorre uma paulatina transformação das palavras que se dissolvem enquanto unidades para dar lugar a outros sons. Esses sons vão criando ondas de profunda vibração e, ao que parece, somente inteligíveis para os especialistas Kaiowá. A reza 
conta sobre a criação do mundo e atualiza o trabalho primordial do casal de demiurgos criadores - Ñanderu e Ñandesy - fazendo ativar um circuito de forças que, por meio dos cantos, faz acontecer a comunicação entre "a terra de baixo", "essa terra que vivemos", e "a terra lá de cima".

As variações de intensidade da reza longa reverberam os imensos desafios desse caminhar cosmológico que vai "levantando" os caminhos em movimento vertical. Portas vão sendo abertas, caminhos de diferentes formas - aquáticos, terrestres, com matas ou campos, de fogo, aéreos - vão sendo atravessados e só os cantos podem criar os veículos e recursos para atravessá-los. A palavra mesmo de Ñanderu e Ñandesy, no último patamar de yvay - a terra lá de cima - especialmente na região conhecida como Yvãga só se escuta indiretamente pois é muito sagrada e é pronunciada como palavras na forma de raios e trovões. Todo esse complexo circuito envolve torres de transmissão (jekoka), segundo Valdomiro e Tereza, localizados no Brasil e no Paraguai, assim como os rios, os cerros, as constelações, os ventos, as plantas e os animais.

É claro que essa breve caracterização da centralidade da reza longa para afirmação do teko Kaiowá e para o casal de xamãs, bem como tudo o que ela implica, justifica porque eles gostariam de ensinar com e pela reza. No entanto, vale também retomar o sentido da palavra ñembo'e, formada por outras duas palavras, o substantivo "ñe'ée e verbo " $e$ ", unidos pela partícula "mbo". Mbo, segundo uma definição dicionarizada é "prefixo de voz coativa, equivalente a fazer + infinitivo no português. Usa-se para formar verbo transitivo direto, a partir de verbo intransitivo" (ASSIS, 2008, p. 216). "E" é a forma infinitiva do verbo falar, dizer. Mbo'e seria "Fazer dizer" ou "fazer falar". É o verbo que se usa para ensinar, instruir. Ensinar é, portanto, fazer dizer, fazer falar. Com mbo'e se escreve professor/professora (mbo'ehara, aquele ou aquela que faz falar) e estudante (mbo'epyra, aquele ou aquela que faz falar em ${ }^{14}$.

Mas o que fala? Ñe'é é traduzido na literatura etnológica guaranítica como palavra e como alma ou como palavra-alma. A primeira tradução foi de León Cadogan (1959) e permaneceu sendo repetida dessa forma até ser revisada por Sandra Benites (2018), pedagoga e antropóloga ñandeva. Segundo essa intelectual, que tem o Guarani como língua materna, essa tradução traz uma visão cristã da existência que em nada dialoga com a visão que perpassa as diversas matrizes da experiência guarani. Diz Ara Rete, Sandra Benites:

"Muitos pesquisadores Juruá, entre eles León Cadogan no clássico Ayvu Rapyta, traduziram (e continuam atribuindo o mesmo significado) o termo nhe'é como "palavra-alma". No contexto em que estou discutindo esse conceito guarani, vejo um equívoco nessa tradução, consequentemente em seu significado. Na língua guarani, ã é alma, que significa 'o que está junto o tempo todo com você, como se fosse uma sombra’. Para o meu povo, isso não é visto como sagrado. Por exemplo, ao nascer uma criança, ela fica 8 dias sem ser vista por ninguém diferente dos seus pais, avós, as

\footnotetext{
${ }^{14}$ Reflexões de tradução realizadas em parceria com Daniel Lemes Vasquez e Johnn Nara Gomes.
} 
pessoas mais próximas. Isso porque alguém com a alma ruim, "pesada", com "energia negativa", pode afetar o ambiente e inclusive o mitã pytaî́-recém nascido" (BENITES, 2018, p. 107).

Se alma é ã ñe'ē não poderia ser alma. Assim, a pesquisadora prefere dar outra tradução consubstanciada no significado experiencial da palavra que sublinha sua multiplicidade, pois não se trata nem de alma, nem de uma, como também sublinha seu caráter sagrado e relacional:

\begin{abstract}
"gostaria de explicar que para nós Guarani existem alguns tipos de Nhe'ẽ, que sentimos no py'a - coração. Mas isso depende da situação vivida por cada indivíduo, depende também do contexto, ou seja, do momento. Depende muito do outro, do lugar onde a pessoa está construindo o seu reko/teko - jeito de ser e viver. Existe nhe'é miri, nhe'ẽ kangy, nhe'ẽ mbarete, nhe'ẽ potĩ, nhe'ẽ poxy, nhe'ẽ mby'a guaxu, nhe'ẽ vy'a. Todos estão relacionados com os nomes Guarani, com o espírito-nome, mas também com o modo de ser de cada kyrin - criança, futuramente adulto. Esses nhe'é kuery nos ajudam a lidar com as mitã - crianças pequenas, kunumi- menino e kunhantãi guemeninas. Desse modo, seguimos nos costumes, o que nos ajuda a construir o ser guarani ete'i - verdadeiro, ou seja, preservar o modo de ser guarani e dar continuidade ao sistema guarani" (BENITES, 2018, p. 107).
\end{abstract}

Tomando de empréstimo esta revisão, ñe'é é o espirito-nome. Ñembo'e, então, poderia ser traduzida como fazer falar o espírito-nome. Os processos de ensinoaprendizagem presentes na reza longa que, como dizem os xamãs Valdomiro e Tereza, é onde está toda a sabedoria Kaiowá, referem-se a um longo caminho (tape puku) do espíritonome, em sua construção aberta e indeterminada, variável e múltipla, perigosa e maravilhosa, que se dá em face de uma existência compósita, de longuíssima duração na memória ancestral e ativada nas práticas cotidianas do bom viver (teko porã).

\title{
A ALIANÇA: FAZER DIFERENÇA + FAZER PRESENÇA = RISCOS
}

Figura 7. "Updated. Meme". Obra de Jota Mombaça, 2017.

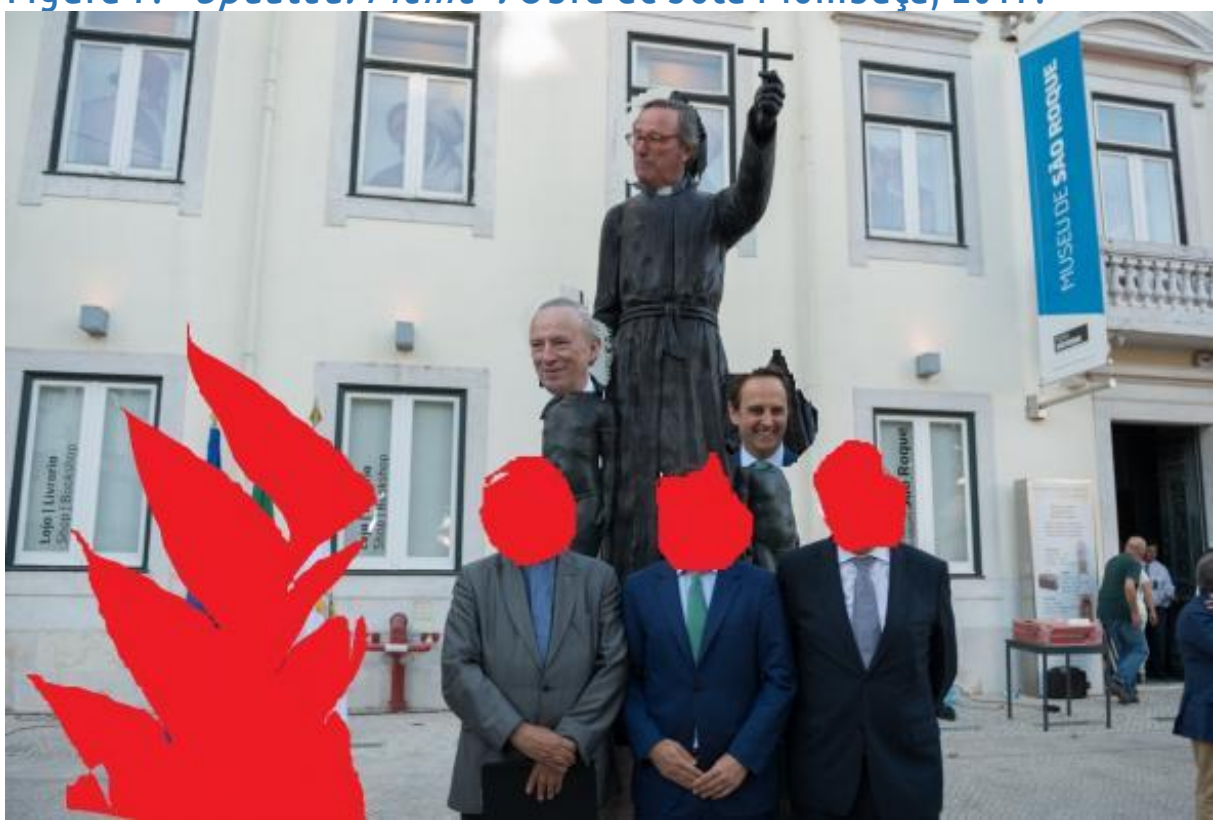

Fonte: www.buala.org 
A artista brasileira Jota Mombaça é bastante crítica às alianças entre pessoas brancas e pessoas racializadas. Na obra acima, "Updated. Meme", faz burla com colagens que suprimem e deslocam os rostos de homens brancos e intelectuais portugueses numa imagem da inauguração estátua do Padre Antônio Vieira no Largo Trindade Coelho em Lisboa/Portugal, além de substituir por formas em vermelho os rostos dos que estavam ali presentes na imagem original. O engenho é evidenciar que o pensamento que se coloca como aliado em debates sobre antirracismo e decolonialidade nem sempre vai de mãos dadas com uma política concreta de redistribuição de poder nas formas de visibilização de pessoas racializadas operada por pessoas brancas. Um certo divórcio entre a retórica dos efeitos de pensamento e os saldos dos efeitos políticos em sua pragmática cotidiana e histórica. Tudo isso animado pela figura emblemática de Vieira, adorado na cultura portuguesa como "sensível à humanidade das gentes que viviam nas terras do que hoje chamamos Brasil" e que traz ainda reminiscências à ideia de uma colonização branda por parte de Portugal, reafirmando "um lugar de fala cujo protagonismo é branco-colonial" (MOMBAÇA, 2017, s/p). Como pensar, então, a aliança entre intelectuais brancas e intelectuais indígenas, entre universidade e comunidades de saberes tradicionais? Рага Mombaça (2017):

\begin{abstract}
"O trabalho político dessas pessoas [brancas aliadas] deve, necessariamente, operar conforme um certo programa negativo, em que desaprender, desfazer, calar e boicotar deixam de ser mecanismos acionados contra pessoas negras e dissidentes em geral para converter-se numa espécie de ética autodestrutiva da qual o trabalho de aliança branca depende" (MOMBAÇA, 2017, s/p)
\end{abstract}

As formas de vida que insistem na fabricação da diferença convocam-nos a somar em suas lutas como potenciais forças de fabricação de presença ou de redistribuição de lugares de presença. Assim se Valdomiro e Tereza junto com seu povo e sua resistência operam tecnologias de produção do comum e da diferença a partir de sua ontoepistemologia, parece que a aliança é possível se nós, desde um lugar de afirmação das reparações históricas e da justiça epistêmica utópica, nos colocarmos a tarefa de sermos produtores de presença. E produzir a presença envolve muitos gestos de acolhimento e coabitação. À escuta e em afetação (corporal, sensível, cognitiva), envolve cuidado e respeito, seja no acompanhamento das aulas, das situações de conversação entre discentes e mestres/mestras educadores, nas formas organizacionais tensas de implementação das iniciativas como projetos institucionais. Isso muitas vezes implica desvanecer, não aparecer, calar, dar um passo atrás, aprender a aprender.

A cosmopráxis do casal de xamãs Tereza e Valdomiro - seja no na universidade e no encontro de saberes onde colaboram para construir protocolos (CARVALHO, 2018) para a comunicação intermundos, seja no tekoha - aproxima-os, em termos pedagógicos, do que 
temos chamado de educadores (não de professores). Nesse sentido, ele e ela ensinam a discentes e docentes da universidade sobre a tomada da palavra (ñe'ê). Quando realizado no tekoha, esse trabalho ocupa vários momentos do dia (as rodas de chima e tereré, as atividades na roça, os momentos de caça, coleta e pesca, preparação de alimentos, preparação de remédios, rodas de dança e canto e, com maior ênfase, o ritual da reza longa), várias espacialidades (a casa, o pátio, a mata, a roça, a casa de reza, o rio) e inclui a observação detalhada de comportamentos e características físicas de cada pessoa humana e não-humana, não raro associadas com as de ancestrais próximos e distantes. Algo que não trata de conteúdos que devam ser repassados e absorvidos mecanicamente, mas de um trabalho de diálogo com o espírito-nome que ensina a todas as partes envolvidas no processo. Nota-se, pois, que o problema da transformação está em questão e, mais além, o domínio sobre a instabilidade da perspectiva e o cuidado de si - não do ego individual, mas do espírito-nome com todos os elos de parentesco e riscos de alteridade bem como todas as possibilidades de comunicação e sociabilidade que ele descortina. A transformação como risco e também como poder.

O princípio do ñembo'e aporta a potência de diálogo com as perspectivas críticas da aprendizagem como tomada da palavra, agora não somente no plano das conversações de uma forma de vida, mas a partir de seu alargamento para a comunicação intermundos. Tais aproximações, equívocas e inequivalentes, indicam possibilidade de diálogos a partir de ñembo'e, fazer falar, plenos de consequências para os impactos de aliança dos quais Valdomiro e Tereza falam. A palavra, como tomada do poder sobre a linguagem/existência que recria a relação na diferença, sugere ser um ponto que nos enlaça. "Hayhun", amor, como dizia emocionado Valdomiro, também parece tornar próximo o que vem de muito longe. Quando nossos corpos e nossos mundos se encontram, com todas as dificuldades que perpassam esse encontro - linguísticas, culturais, étnico-raciais, de estilo, de classe, de regime científico e tecnológico - é encontro de saberes porque estamos, dentre outras coisas, aprendendo a nos encontrar.

Em face disso, encontro de saberes é também uma conduta que, por vezes, se traduz em gesto ético-político em favor de um outro pacto de inserção na vida universitária. É um intento concreto de insurgência epistêmica. O encontro é o que pode nutrir, em intelectuais brancos, a ação intelectual de afirmação, aprendizagem e intentos de comunicação regidos por lógicas experimentais com formas de vida contra-coloniais (SANTOS, 2015). Estas, por sua vez, em contextos institucionais permeados de colonialidade como a universidade trazem a potência de precipitar algo em favor de sua descolonização. É claro que a opção do encontro está prenhe de tensões, auto-críticas, desentendimentos, equívocos, tentativas, mas opera a crítica aos sistemas de saber-poder dominantes não de um lugar distanciado (em muitos casos, ainda nutrido por uma atitude de superioridade 
colonial, como aponta Jota Mombaça) mas de um lugar implicado no qual efeitos de pensamento sejam também efeitos políticos com amplo poder de afetação e de aprendizagem como diálogo.

\section{REFERÊNCIAS}

ALMEIDA, R. F. T. Do Desenvolvimento Comunitário à Mobilização Política: o Projeto Kaiowá-Ñandeva como Experiência Antropológica. Rio de Janeiro: Contra Capa Livraria, 2001.

ASSIS, C. F. de. Ñe'e ryru: avañeē'-Portuge/Portuge-Avañēe’'. Dicionário Guarani-português/Português Guarani. 2a ed. São Paulo: Edição da autora, 2008.

BENITES, Sandra. Ore Arandu (nosso conhecimento guarani): sobre Nheê-espirito-nome. Revista Jesus Histórico XI, v. 20, p. 104-121, 2018.

BENITES, T. Rojeroky hina ha roike jevy tekohape (Rezando e lutando): o movimento histórico dos Aty Guasu dos Ava Kaiowá e dos Ava Guarani pela recuperação de seus tekoha. Tese deDoutorado em Antropologia Social - PPGAS/Museu Nacional - Universidade Rural do Rio de Janeiro, 2014.

BRAND, A. J. 0 confinamento e seu impacto sobre os Paì-Kaiowá. Dissertação de Mestrado em História - Pontifícia Universidade Católica de Porto Alegre, 1993.

0 impacto da perda da terra sobre a tradição kaiowá/guarani: os difíceis caminhos da palavra. Tese de Doutorado em História - PUC/ RS, Pontifícia Universidade Católica, 1997.

BUTLER, J. Quadros de Guerra: quando a vida é passível de luto?. $1^{\text {a }}$ ed. Rio de Janeiro: Civilização Brasileira, 2015.

CADOGAN, L. Ayvu Rapyta. textos míticos de los Mbyá-Guarani. Boletim 227. Antropologia 5, FFLCH, São Paulo: Universidade de São Paulo, 1959.

CARVALHO, J. J. Encontro de Saberes e Descolonização: para uma refundação étnica, racial e epistêmica das universidades brasileiras. In: BERNARDINO-COSTA, J.; MALDONADO-TORRES, N.; GROSFOGUEL, R. Decolonialidade e Pensamento Afrodiaspórico. Belo Horizonte: Autêntica, 2018. p. 79-106.

CHAMORRO, G. Terra Madura/Yvy Araguye: Fundamento da Palavra Guarani. Dourados: Editora da UFGD, 2008.

Nhanduti Editora, 2015.

História Kaiowá: das origens aos desafios contemporâneos. São Bernardo do Campo:

CUNHA, M. C. Índios no Brasil: História, Direitos e Cidadania. São Paulo: Claro Enigma, 2012.

FLORES, V. Disciplina Artes Ofícios dos Saberes Tradicionais. [Aula]. Módulo Cosmociência Kaiowá. Tradução de Genito Gomes e Valmir Gonçalves Cabreira. Belo Horizonte: UFMG, 2014.

Formação Transversal em Saberes Tradicionais [Aula]. Disciplina Ojuhu Ñe'e/Mbopaje Ñe'e. Encontrar a palavra/Encantar a palavra. Tradução de Genito Gomes e Daniel Lemes Vasques. Belo Horizonte: UFMG, 2016. 
FLORES, T. A. Políticas da Terra. Formação Transversal em Saberes Tradicionais [Aula]. Módulo Políticas da Terra Kaiowá. (Tradução de Jhonn Nara Gomes). Belo Horizonte: UFMG, 2018.

FLORES, V.; FLORES, T. A. OLIVEIRA, L. Ñe'ē Tee Rekove/Palavra Verdadeira Viva. Belo Horizonte, PPGCOM/FAFICH/UFMG, 2020.

FREIRE, J. R. de B. Cinco ideias equivocadas sobre o índio. Revista do Centro de Estudos do Comportamento Humano (CENESCH). Manaus, n. 01, setembro/2000. Pp 17-33.

GOMES, M. P. Os índios e o Brasil: passado, presente e futuro. São Paulo: Contexto, 2012. P. 140-170.

GRUPIONI, L. D. B. (org.). 4. ed. Índios no Brasil. São Paulo: Global Editora; Brasília: MEC, 2000.

JOÃO, I. Jakaira Reko Nhepiru Marangatu Mborahei: origem e fundamentos do canto ritual Jerosy Puku entre os Kaiowá de Panambi, Panambizinho e Sucuri'y. Dissertação de Pós-Graduação em História - Faculdade de Ciências Humanas/UFGD, 2011.

KRENAK, A. Ideias para adiar o fim do mundo. São Paulo: Companhia das Letras, 2019.

MBEMBE, A. Necropolítica. Arte \& Ensaios: Revista do PPGAV/EBA/UFRJ, n. 32, dez., 2016.

MELLATI, Júlio César. Índios do Brasil. Edusp, São Paulo, 2007.

MOMBAÇA, J. A coisa tá branca! Buala, Lisboa, 2017. Disponível em: https://www.buala.org/pt/mukanda/a-coisa-ta-branca Acesso em 01 de junho 2020.

MONTARDO, D. L. 0 kotyhu ou guaxire, um gênero de canto/dança dos Guarani do MS. Anais do III Encontro Internacional da Associação Brasileira de Etnomusicologia: Cultura, sociabilidade e política das práticas musicais. São Paulo, ABET, 2006. Disponível em: https://studylibpt.com/doc/3312249/anaisiii-enabet--associa\%C3\%A7\%C3\%A30-brasileira-de-etnomusicologia. Acesso em 27 de novembro de 2018.

PEREIRA, L. Os kaiowá em Mato Grosso do Sul: módulos organizacionais e humanização do espaço habitado. Dourados: UFGD, 2016.

PIMENTEL, S.. Elementos para uma teoria política kaiowá e guarani. Tese de Pós-Graduação em Antropologia Social - Faculdade de Filosofia, Letras e Ciências Humanas, Universidade de São Paulo, 2012.

RODGERS, A. P. L. et al. A memória das canções como um território de resistência entre os povos indígenas da América do Sul. Um projeto coletivo de documentação. In: LUHNING, A.; TUGNY, R. P. (Org.). Etnomusicologia no Brasil. Salvador: Edufba, v. 1, 2017. p. 139-183.

ROLNIK, Raquel. Guerra dos Lugares: A colonização da terra e da moradia na era das finanças. Rio de Janeiro, Boitempo editorial, 2015.

SCHADEN, E. Aspectos Fundamentais da Cultura Guarani. São Paulo: Difusão Europeia do Livro, 1962.

SANTOS, A. B. Colonização, quilombos: modos e significações. 1a ed. Brasília, INCTI/UNB, 2015. 